\title{
Production Performance, Egg Quality, and Fecal Bacterial Population of Laying Ducks Fed Ration Supplemented by Bamboo Vinegar
}

\author{
J. Rattanawut ${ }^{\mathrm{a}, *}$, D. Trairabeap ${ }^{\mathrm{a}}$, S. J. Karrila ${ }^{\mathrm{a}}$, P. Rodjan ${ }^{\mathrm{b}}$, \& Y. Theapparat ${ }^{\mathrm{c}}$ \\ ${ }^{a}$ Faculty of Science and Industrial Technology, Prince of Songkla University, \\ Surat Thani Campus, Surat Thani, Thailand \\ 'Program in Tropical Agricultural Resource Management, Faculty of Natural Resources, \\ Prince of Songkla University, Hat Yai, Thailand \\ 'Drug Delivery System Excellence Center, Department of Pharmaceutical Technology, Faculty of Pharmaceutical \\ Sciences, Prince of Songkla University, Hat Yai, Thailand \\ Corresponding author: jassada.r@psu.ac.th \\ (Received 01-05-2019; Revised 27-08-2019; Accepted 29-08-2019)
}

\begin{abstract}
With the ban on the use of antibiotics in poultry feed, it is required to produce alternative substances to maintain poultry health and performance. The present study was carried out to investigate the effects of dietary supplementation at various levels of bamboo vinegar (BV) on performance, egg quality, and fecal bacterial population of laying ducks. One hundred and five 50-week-old crossbred laying ducks (Khaki Campbell $\times$ Native) were randomly allocated into five treatment groups, each with seven replicates of three ducks. The experimental ducks were fed a basal diet (antibiotic-free diet) supplemented with BV at the levels of $0 \%, 0.2 \%, 0.4 \%, 0.6 \%$, or $0.8 \%$ of diet until 62 weeks of age. For the overall period (from 50 to 62 weeks of age), the dietary supplementation of BV at the levels of $0.4 \%$ and $0.6 \%$ of diet increased egg production and egg mass, and improved feed efficiency of laying ducks $(\mathrm{p}<0.01)$. Supplementation of $\mathrm{BV}$ at the level of $0.8 \%$ in the diet decreased feed intake $(p<0.01)$. Egg quality parameters were not significantly affected by supplementation of BV ( $p>0.05)$. The population of fecal Escherichia coli was significantly decreased in the experimental ducks fed diet supplemented with $\mathrm{BV}$ at the levels of $0.4 \%, 0.6 \%$, and $0.8 \%$ compared to the control group $(\mathrm{p}<0.01)$, while the population of Lactobacillus spp. remained unchanged. The present results indicate that a level of $0.4 \%$ BV supplementation in laying duck diet is sufficient for reducing fecal E. coli and improves productive performance of egg laying ducks.
\end{abstract}

Keywords: bamboo vinegar; egg quality; fecal bacteria; laying ducks

\section{INTRODUCTION}

Antibiotics have been commonly included at the sub-therapeutic doses in poultry diets for improving performance and maintaining the optimal health of the birds. However, there is a growing concern that the use of antibiotics in poultry feed selects for the evolution of antibiotic-resistant pathogens, as well as causes antibiotic residue problems in poultry products. As a result, the poultry industry has been compelled to find alternatives for antibiotics. Dietary acidifiers appear to be potential alternatives to the antibiotics for improving poultry performance and preventing diseases. The beneficial effects of acidifiers include the enhancing growth rate through the improved gut health through the reduced $\mathrm{pH}$, promoting the growth of beneficial bacteria, and increasing the digestibility of nutrients through the improved pancreatic secretion (Papatsiros \& Christodoulopoulos, 2011). Besides, acidifiers have antimicrobial activity in controlling the bacterial populations in the gut and inhibiting the growth of pathogenic bacteria (Kil et al., 2011). It was shown that acidifiers in broiler diets increased weight gain and improved feed efficiency (Hedayati et al., 2013). In laying hens, acidifiers in the diets also improve egg production and eggshell quality (Swiatkiewicz et al., 2010). Bamboo vinegar (BV) is an acidic by-product of bamboo charcoal production. It is composed of water, and many other organic constituents, and has a pH of 2.5 to 3.0 (Akakabe et al., 2006; Velmurugan et al., 2009; Huo et al., 2016). Akakabe et al. (2006) reported that there were many similarities between the components of bamboo vinegar and those of wood vinegar. Wood vinegar exhibits high antimicrobial activities against various microorganisms, along with a significant antioxidant activity (Yang et al., 2016). Bamboo vinegar also acts as an insecticide and bactericide and is used as a component in folk medicine (Akakabe et al., 2006). Positive effects of feeding BV to pigs have been reported from several studies (Yan et al., 2012; Chu et al., 2013; Huo et al., 2016). However, the applications of BV in poultry have not been vigorously investigated, and there was no prior study examining the effects of BV supplementation in laying ducks. The objective of this study, therefore, was to examine the effects of dietary supplementation of BV at various levels on egg production performance, internal and external 
egg qualities, and fecal bacterial populations in laying ducks.

\section{MATERIALS AND METHODS}

\section{Birds and Management}

The experiment in its totality was conducted following the guidelines and rules for animal experiments of Prince of Songkla University, Thailand. A total of 105 crossbred laying ducks (Khaki Campbell $\times$ Native) at 50 weeks of age were randomly assigned into five treatments, and each treatment group consisted of 7 replicates with 3 birds in each replicate. The ducks were housed in $40 \mathrm{~cm} \times 45 \mathrm{~cm} \times 35 \mathrm{~cm}$ cages (three ducks per cage), in an environmentally controlled room under a photoperiod of $18 \mathrm{~h}$ of light. The basal diet (Table 1) was formulated to meet the nutrient recommendations of the NRC (1994). The ducks were fed a basal diet supplemented with BV at the levels of $0 \%, 0.2 \%, 0.4 \%, 0.6 \%$, or $0.8 \%$ of diet $(\mathrm{v} / \mathrm{w})$ until 62 weeks of age. Commercial $\mathrm{BV}(\mathrm{pH}=3.0)$ was purchased from a company (Charcoal Home Co., Ltd., Bangkok, Thailand) and select physicochemical characteristics of this bamboo vinegar are shown in Table 2. Feed and water were provided ad libitum throughout the 12 weeks of treatment.

\section{Performance and Egg Quality Parameters}

Production performance was examined every 4 weeks by measuring feed intake, egg production, egg

Table 1. Feed formulation and chemical composition of experimental diet (as-fed basis)

\begin{tabular}{lc}
\hline \multicolumn{1}{c}{ Item } & Amount (\%) \\
\hline Ingredient & \\
Corn & 59.25 \\
Soybean meal $(44 \% \mathrm{CP})$ & 24.40 \\
Raw rice bran & 4.00 \\
Fish meal $(55 \% \mathrm{CP})$ & 2.00 \\
Calcium carbonate $(38 \% \mathrm{Ca})$ & 7.95 \\
Dicalcium phosphate $(18 \% \mathrm{P})$ & 1.40 \\
Rice bran oil & 0.40 \\
Salt & 0.30 \\
Premix ${ }^{1}$ & 0.30 \\
Calculated analysis & \\
Crude protein & 17.00 \\
Metabolizable energy $(\mathrm{kcal} / \mathrm{kg})$ & 2,700 \\
Crude fiber & 3.61 \\
Crude fat & 3.57 \\
Calcium & 3.60 \\
Available phosphorus & 0.35 \\
Lysine & 0.90 \\
Methionine & 0.40 \\
Methionine+Cysteine & 0.70 \\
\hline
\end{tabular}

${ }^{1}$ Composition per $1 \mathrm{~kg}$ premix: 20.0 MIU vitamin A, 4.0 MIU vitamin D3, 22,000 mg vitamin $\mathrm{E}, 4 \mathrm{~g}$ vitamin $\mathrm{K} 3,5 \mathrm{~g}$ vitamin $\mathrm{B} 1,10 \mathrm{~g}$ vitamin $\mathrm{B} 2,6$ $\mathrm{g}$ vitamin B6, $0.06 \mathrm{~g}$ vitamin B12, $50 \mathrm{~g}$ nicotinic acid, $20 \mathrm{~g}$ pantothenic acid, $0.24 \mathrm{~g}$ biotin, $3 \mathrm{~g}$ folic acid, $15 \mathrm{~g}$ vitamin $\mathrm{C}, 23.4 \mathrm{~g}$ feed additives, up to $1 \mathrm{~kg}$ filter.
Table 2. Chemical properties of bamboo vinegar liquid

\begin{tabular}{|c|c|}
\hline Compound & $\begin{array}{c}\text { Relative } \\
\text { concentration }(\%)\end{array}$ \\
\hline \multicolumn{2}{|l|}{ Organic acids } \\
\hline Acetic acid & 47.59 \\
\hline Formic acid & 0.33 \\
\hline Propionic acid & 3.31 \\
\hline 4-oxo-pentanoic acid & 0.40 \\
\hline Benzoic acid & 0.35 \\
\hline Total organic acids & 51.98 \\
\hline \multicolumn{2}{|l|}{ Alcohols } \\
\hline Benzene methanol & 1.90 \\
\hline Total alcohols & 1.90 \\
\hline \multicolumn{2}{|l|}{ Furans } \\
\hline \multicolumn{2}{|l|}{ 2-methyl-furan } \\
\hline Tetrahydro-2-furanmethanol & 0.29 \\
\hline Dihydroxy-2(3H)-furanone & 3.35 \\
\hline 2-furanmethanol & 0.36 \\
\hline 3-hydroxy-2methyl-2H-pyran-4-one & 1.69 \\
\hline 2-furancarboxaldehyde & 0.97 \\
\hline 5-methyl-2-furancarboxaldehyde & 0.32 \\
\hline 2-(2,3-epoxypropyl)-tetrahydrofuran & 5.60 \\
\hline 1,4:3,6-dianhydro-alpha-d-glucopyanose & 0.36 \\
\hline Total furans & 12.94 \\
\hline \multicolumn{2}{|l|}{ Phenol derivatives } \\
\hline Phenol & 5.14 \\
\hline 3-methylphenol & 0.44 \\
\hline Total phenol derivatives & 5.58 \\
\hline \multicolumn{2}{|l|}{ Methoxy phenol derivatives } \\
\hline 2-methoxyphenol & 2.26 \\
\hline 4-methyl-2-methxyphenol & 0.70 \\
\hline 4-ethyl-2-methoxyphenol & 0.38 \\
\hline 4-methylsyringol & 4.08 \\
\hline Total methoxy phenol derivatives & 7.42 \\
\hline \multicolumn{2}{|l|}{ Aldehyde and ketones } \\
\hline 1-hydroxy-2-butanone & 0.36 \\
\hline 1-hydroxy-2-propanone & 0.91 \\
\hline 3-methyl-2-cyclopenten-1-one & 0.47 \\
\hline 2,3-dimethyl-2-cyclopenten-1-one & 0.51 \\
\hline 2-hydroxy-3methyl-2 cyclopenten-1-one & 1.32 \\
\hline 3-ethyl-2-hydroxy-2-cyclopenten-1-one & 0.31 \\
\hline 1-(2-furanyl)-ethanone & 0.26 \\
\hline 2-nitro-propionate(ester)ethanol & 0.47 \\
\hline Total aldehyde and ketones & 4.61 \\
\hline \multicolumn{2}{|l|}{ Heterocyclic aromatic compound } \\
\hline Pyridine & 1.37 \\
\hline 2-methylpyridine & 0.25 \\
\hline 3-methylpryridine & 0.25 \\
\hline 3-methoxypyridine & 1.06 \\
\hline 11,2,3-trimetoxy-5-methylbenzene & 0.27 \\
\hline Total heterocyclic aromatic compounds & 3.20 \\
\hline \multicolumn{2}{|l|}{ Other compounds } \\
\hline 3,5-dimethoxy-4-hydroxytoluene & 0.39 \\
\hline Phospholane & 0.33 \\
\hline 1-etnoxy-10-methylundec-1-yne & 0.29 \\
\hline Total other compounds & 1.01 \\
\hline
\end{tabular}


weight, egg mass, and feed efficiency. Body weight was recorded at the beginning and the end of experiments (at 50 and 62 weeks of age, respectively). Egg quality was estimated every 4 weeks (weeks 54,58, and 62) by measuring the egg weight, eggshell weight, eggshell percent, eggshell strength, eggshell thickness, yolk percent, albumen percent, yolk color score, and Haugh unit. The weights of the eggs from each group were recorded, and the breaking strength of the eggshell $\left(\mathrm{kg} / \mathrm{cm}^{2}\right)$ was measured using a breaking strength measuring device (DET6000, NABEL Co., Ltd, Kyoto, Japan). The weights of the shell, albumen, and egg yolk were measured using an electronic digital balance and are reported as percentages. Eggshell thickness was measured by a digital micrometer (Mitutoyo Corporation, Japan). The pigmentation of the egg yolk and Haugh unit scores were measured using the digital egg tester (DET6000, NABEL Co., Ltd).

\section{Fecal Bacterial Analyses}

At 62 weeks of age, samples of fresh feces (7 samples/diet) were collected aseptically in vinyl bags, and a $1 \mathrm{~g}$ subsample was transferred to a test tube. The subsample was mixed with $9 \mathrm{~mL}$ of phosphate-buffered saline and homogenized at 2,500 rpm for $30 \mathrm{sec}$. The homogenized sample was serially diluted between $10^{-2}$ to $10^{-5}$ fold. Escherichia coli was grown on EMB agar (BBL, Sparks, MD, USA) and incubated at $37^{\circ} \mathrm{C}$ for $24 \mathrm{~h}$. Lactobacillus spp. was grown on lactobacillus MRS agar (HiMedia LAB, Mumbai, India) and incubated at $37^{\circ} \mathrm{C}$ for $48 \mathrm{~h}$. The colonies on each plate were counted, and the results were expressed as $\log _{10}$ CFU per gram of fresh sample.

\section{Statistical Analysis}

Collected data were subjected to one-way analysis of variance, followed by Duncan's multiple range test to find out the level of significance in differences between the mean values. Differences with $\mathrm{p}<0.05$ were considered significant.

\section{RESULTS}

\section{Performance}

Table 3 shows the production performances of laying ducks. Compared to the control group, egg production significantly increased in the ducks fed diet

Table 3. Performance of laying ducks during 50-62 weeks of age supplemented by different levels of dietary bamboo vinegar (BV)

\begin{tabular}{|c|c|c|c|c|c|c|c|}
\hline \multirow{2}{*}{ Variables } & \multicolumn{5}{|c|}{ Dietary bamboo vinegar (\%) } & \multirow{2}{*}{ SEM } & \multirow{2}{*}{$\mathrm{p}$-value } \\
\hline & 0 & 0.2 & 0.4 & 0.6 & 0.8 & & \\
\hline Initial body weight (g) & $1,319.30$ & $1,325.00$ & $1,330.00$ & $1,328.60$ & $1,314.30$ & 17.08 & 0.990 \\
\hline Final body weight (g) & $1,425.00$ & $1,402.10$ & $1,422.10$ & $1,424.30$ & $1,400.00$ & 16.31 & 0.980 \\
\hline Body weight change (g) & 105.70 & 77.10 & 92.10 & 95.70 & 85.70 & 6.63 & 0.743 \\
\hline \multicolumn{8}{|c|}{ Hen-day egg production (\%) } \\
\hline 51-54 weeks & 72.45 & 73.31 & 79.59 & 76.53 & 71.43 & 1.06 & 0.073 \\
\hline 55-58 weeks & $75.00^{\mathrm{bc}}$ & $75.51^{\mathrm{bc}}$ & $82.65^{\mathrm{a}}$ & $81.63^{\mathrm{ab}}$ & $72.45^{c}$ & 1.18 & 0.014 \\
\hline 59-62 weeks & $73.47^{\mathrm{abc}}$ & $72.45^{\mathrm{bc}}$ & $80.61^{a}$ & $78.57^{\mathrm{ab}}$ & $70.41^{c}$ & 1.25 & 0.040 \\
\hline 51-62 weeks & $73.64^{\mathrm{b}}$ & $73.75^{\mathrm{b}}$ & $80.95^{a}$ & $78.91^{\mathrm{a}}$ & $71.43^{\mathrm{b}}$ & 0.93 & 0.001 \\
\hline \multicolumn{8}{|l|}{ Egg weight (g) } \\
\hline 51-54 weeks & 61.52 & 61.38 & 61.29 & 62.63 & 63.73 & 0.47 & 0.434 \\
\hline 55-58 weeks & 62.28 & 62.76 & 61.39 & 62.37 & 63.56 & 0.30 & 0.249 \\
\hline 59-62 weeks & 62.71 & 63.25 & 63.49 & 64.01 & 63.84 & 0.16 & 0.100 \\
\hline 51-62 weeks & 62.17 & 62.46 & 62.05 & 63.00 & 63.71 & 0.27 & 0.290 \\
\hline \multicolumn{8}{|l|}{ Egg mass (g/hen/day) } \\
\hline 51-54 weeks & 44.57 & 44.99 & 48.78 & 47.93 & 45.52 & 0.76 & 0.177 \\
\hline 55-58 weeks & $46.71^{\mathrm{ab}}$ & $47.39^{\mathrm{ab}}$ & $50.73^{a}$ & $50.91^{\mathrm{a}}$ & $46.04^{\mathrm{b}}$ & 0.68 & 0.048 \\
\hline 59-62 weeks & $46.07^{\mathrm{bc}}$ & $45.82^{\mathrm{bc}}$ & $51.17^{\mathrm{a}}$ & $50.29^{\mathrm{ab}}$ & $44.94^{c}$ & 0.79 & 0.023 \\
\hline 51-62 weeks & $45.78^{\mathrm{b}}$ & $46.06^{\mathrm{b}}$ & $50.22^{\mathrm{a}}$ & $49.71^{\mathrm{a}}$ & $45.50^{\mathrm{b}}$ & 0.58 & 0.004 \\
\hline \multicolumn{8}{|l|}{ Feed intake $(\mathrm{g} / \mathrm{d})$} \\
\hline 51-54 weeks & 140.36 & 138.16 & 139.85 & 138.64 & 137.40 & 0.38 & 0.071 \\
\hline 55-58 weeks & $139.03^{a}$ & $139.90^{\mathrm{a}}$ & $139.80^{\mathrm{a}}$ & $137.83^{\mathrm{a}}$ & $132.86^{b}$ & 0.53 & 0.001 \\
\hline 59-62 weeks & $137.65^{\mathrm{a}}$ & $137.04^{\mathrm{a}}$ & $139.08^{\mathrm{a}}$ & $138.11^{\mathrm{a}}$ & $134.08^{\mathrm{b}}$ & 0.40 & 0.001 \\
\hline 51-62 weeks & $139.01^{a}$ & $138.36^{\mathrm{a}}$ & $139.57^{\mathrm{a}}$ & $138.19^{a}$ & $134.78^{\mathrm{b}}$ & 0.33 & 0.001 \\
\hline \multicolumn{8}{|c|}{ Feed efficiency ( $\mathrm{g}$ of egg mass/g of feed consumed) } \\
\hline $51-54$ weeks & 0.317 & 0.325 & 0.348 & 0.345 & 0.331 & 0.005 & 0.166 \\
\hline $55-58$ weeks & 0.335 & 0.338 & 0.362 & 0.367 & 0.335 & 0.004 & 0.081 \\
\hline $59-62$ weeks & 0.334 & 0.334 & 0.367 & 0.364 & 0.335 & 0.005 & 0.056 \\
\hline 51-62 weeks & $0.328^{\mathrm{b}}$ & $0.332^{\mathrm{b}}$ & $0.359^{a}$ & $0.358^{\mathrm{a}}$ & $0.333^{\mathrm{b}}$ & 0.004 & 0.004 \\
\hline
\end{tabular}

Note: Means in the same row with different superscripts differ significantly $(\mathrm{p}<0.05)$. Values are means of 7 replicates. 
supplemented with BV at the level of $0.4 \%$, during the 55-58 and 59-62 weeks-of-age periods $(\mathrm{p}<0.05)$, and the overall egg production was elevated in the laying ducks fed diet supplemented with BV at the levels of $0.4 \%$ and $0.6 \%(p<0.01)$. The highest egg mass was produced by the ducks fed diet supplemented with $0.4 \%$ BV, during 59-62 weeks-of-age period $(p<0.05)$, and the highest overall egg mass was produced by ducks fed diets supplemented with 0.4 and $0.6 \%$ BV $(p<0.01)$. Feed intake decreased in the ducks fed diet supplemented with BV at the level of $0.8 \%$ during 55-62 weeks-of-age, and across the overall period ( $\mathrm{p}<0.01)$. Overall feed efficiency was better in the ducks fed diet supplemented with BV at the levels of $0.4 \%$ and $0.6 \%(p<0.01)$. Body weight and egg weight did not differ significantly between the different levels of BV supplementations in the diet $(\mathrm{p}>0.05)$.

\section{Egg Quality Parameters}

The BV supplementation in the diet did not affect egg weight, shell weight, shell strength, shell thickness, albumen percent, yolk percent, yolk color score, or Haugh unit $(\mathrm{p}>0.05)$ (Table 4$)$.

\section{Fecal Bacterial Population}

As shown in Table 5, dietary supplementation of BV at the levels of $0.4 \%, 0.6 \%$, and $0.8 \%$ significantly reduced the population of $E$. coli in the feces compared to the control $(\mathrm{p}<0.01)$. However, the fecal Lactobacillus counts did not differ significantly between the treatment groups $(\mathrm{p}>0.05)$.

Table 4. Egg quality traits of laying ducks at 54, 58, and 62 weeks of age supplemented by different levels of dietary bamboo vinegar (BV)

\begin{tabular}{|c|c|c|c|c|c|c|c|}
\hline \multirow{2}{*}{ Variables } & \multicolumn{5}{|c|}{ Dietary bamboo vinegar (\%) } & \multirow{2}{*}{ SEM } & \multirow{2}{*}{ p-value } \\
\hline & 0 & 0.2 & 0.4 & 0.6 & 0.8 & & \\
\hline \multicolumn{8}{|l|}{ Egg weight (g) } \\
\hline 54 weeks & 61.38 & 61.60 & 61.75 & 62.48 & 62.77 & 0.25 & 0.361 \\
\hline 58 weeks & 61.88 & 62.05 & 61.60 & 62.38 & 63.08 & 0.30 & 0.601 \\
\hline 62 weeks & 63.05 & 63.35 & 63.57 & 64.20 & 63.97 & 0.30 & 0.779 \\
\hline \multicolumn{8}{|l|}{ Eggshell weight (g) } \\
\hline 54 weeks & 7.12 & 7.07 & 7.05 & 7.10 & 7.18 & 0.03 & 0.831 \\
\hline 58 weeks & 6.91 & 7.05 & 6.97 & 6.91 & 6.98 & 0.03 & 0.711 \\
\hline 62 weeks & 7.14 & 7.17 & 7.24 & 7.22 & 7.21 & 0.03 & 0.825 \\
\hline \multicolumn{8}{|l|}{ Eggshell percent (\%) } \\
\hline 54 weeks & 11.59 & 11.47 & 11.41 & 11.36 & 11.43 & 0.06 & 0.756 \\
\hline 58 weeks & 11.16 & 11.36 & 11.31 & 11.07 & 11.06 & 0.18 & 0.685 \\
\hline 62 weeks & 11.32 & 11.31 & 11.38 & 11.24 & 11.27 & 0.03 & 0.815 \\
\hline \multicolumn{8}{|c|}{ Eggshell thickness (mm) } \\
\hline 54 weeks & 0.396 & 0.397 & 0.398 & 0.393 & 0.394 & 0.001 & 0.452 \\
\hline 58 weeks & 0.384 & 0.385 & 0.395 & 0.385 & 0.384 & 0.002 & 0.309 \\
\hline 62 weeks & 0.378 & 0.383 & 0.385 & 0.383 & 0.380 & 0.001 & 0.591 \\
\hline \multicolumn{8}{|c|}{ Eggshell strength $\left(\mathrm{kg} / \mathrm{cm}^{2}\right)$} \\
\hline 54 weeks & 4.64 & 4.77 & 4.86 & 4.68 & 4.61 & 0.10 & 0.949 \\
\hline 58 weeks & 4.34 & 4.58 & 4.59 & 4.24 & 4.22 & 0.11 & 0.732 \\
\hline 62 weeks & 4.16 & 4.36 & 4.30 & 4.38 & 4.29 & 0.07 & 0.895 \\
\hline \multicolumn{8}{|l|}{ Albumen percent (\%) } \\
\hline 54 weeks & 55.46 & 56.39 & 56.02 & 55.50 & 55.59 & 0.25 & 0.746 \\
\hline 58 weeks & 57.44 & 56.85 & 56.46 & 56.23 & 56.67 & 0.25 & 0.644 \\
\hline 62 weeks & 57.36 & 57.16 & 56.68 & 56.62 & 56.71 & 0.21 & 0.759 \\
\hline \multicolumn{8}{|l|}{ Yolk percent (\%) } \\
\hline 54 weeks & 32.95 & 32.14 & 32.57 & 33.14 & 32.98 & 0.25 & 0.755 \\
\hline 58 weeks & 31.40 & 31.79 & 32.23 & 32.70 & 32.27 & 0.24 & 0.522 \\
\hline 62 weeks & 31.32 & 31.53 & 31.94 & 32.14 & 32.02 & 0.21 & 0.742 \\
\hline \multicolumn{8}{|l|}{ Yolk color score } \\
\hline 54 weeks & 7.58 & 7.27 & 7.60 & 7.25 & 7.47 & 0.06 & 0.278 \\
\hline 58 weeks & 7.37 & 7.07 & 7.81 & 7.25 & 7.15 & 0.10 & 0.141 \\
\hline 62 weeks & 7.28 & 7.64 & 7.38 & 7.44 & 7.75 & 0.08 & 0.382 \\
\hline \multicolumn{8}{|l|}{ Haugh unit } \\
\hline 54 weeks & 88.87 & 89.58 & 88.67 & 89.75 & 90.10 & 0.58 & 0.941 \\
\hline 58 weeks & 83.68 & 85.08 & 84.84 & 85.60 & 85.20 & 0.51 & 0.837 \\
\hline 62 weeks & 84.52 & 85.32 & 86.14 & 86.35 & 85.44 & 0.44 & 0.734 \\
\hline
\end{tabular}

Note: Values are means of 7 replicates. 
Table 5. Fecal bacteria count ( $\log 10 \mathrm{cfu} / \mathrm{g}$ of fresh feces) of ducks fed diet supplemented by bamboo vinegar (BV) at the levels of $0 \%$, $0.2 \%, 0.4 \%, 0.6 \%$, and $0.8 \%$

\begin{tabular}{|c|c|c|c|c|c|c|c|}
\hline \multirow{2}{*}{ Variables } & \multicolumn{5}{|c|}{ Dietary bamboo vinegar (\%) } & \multirow{2}{*}{ SEM } & \multirow{2}{*}{$\mathrm{p}$-value } \\
\hline & 0 & 0.2 & 0.4 & 0.6 & 0.8 & & \\
\hline Escherichia coli & $8.86^{\mathrm{a}}$ & $8.87^{a}$ & $8.83^{\mathrm{b}}$ & $8.82^{\mathrm{b}}$ & $8.81^{b}$ & 0.005 & 0.001 \\
\hline Lactobacillus spp. & 9.01 & 9.02 & 9.02 & 9.03 & 9.02 & 0.004 & 0.480 \\
\hline
\end{tabular}

Note: Means in the same row with different superscripts differ significantly $(p<0.01)$. Values are means of 7 replicates.

\section{DISCUSSION}

In a recent study with aged laying hens, we found that feeding BV at the level of $0.4 \%$ or $0.8 \%$ of the diet beneficially affected damaged egg rate, but did not influence egg production (Rattanawut et al., 2018). In the present study, adding $0.4 \%$ or $0.6 \% \mathrm{BV}$ in the feed increased egg production performance and improved feed efficiency of ducks during the whole experiment (51-62 weeks of age). The improved laying performance as a result of dietary BV supplementation might be due to the beneficial effects of $\mathrm{BV}$ through the improved gastrointestinal tract environment. Bamboo vinegar contains more than 200 accessory ingredients, including organic acids, phenols, ketones, and aldehydes (Akakabe et al., 2006). Organic acids are the main component in bamboo vinegar (Table 2). The main actions of organic acids in the gut are modifying the $\mathrm{pH}$ and controlling the balance of intestinal microflora and pathogens. A low gizzard $\mathrm{pH}$ improves pepsin activity and increases the solubility of the mineral fraction of the diet (Mabelebele et al., 2014). These changes, in turn, are expected to improve the digestibility of nutrients and to enhance product performance. The concentration of phenolic compounds in bamboo vinegar is 3-4 folds that in wood vinegar (Velmurugan et al., 2009). Some phenolic compounds have been reported to inhibit pathogenic bacteria (Pacheco-Ordaz et al., 2017). Chan et al. (2012) reported that wood vinegar displayed potent antibacterial activity against the strains of Gram-negative Escherichia coli, Salmonella typhi, and Pseudomonas aeruginosa. In this study, bamboo vinegar might also have a direct effect on the digestive tract bacterial populations, reducing the number of some pathogenic bacteria and controlling the populations of certain types of bacteria that compete with the host bird for nutrients. Therefore, the positive effects of $0.4 \%$ and $0.6 \% \mathrm{BV}$ supplementation on productive performance observed in this study might be related to the bioactive components in BV, such as organic acids, phenolic compounds, and heterocyclic compounds. In the present study, supplementing the diet with $0.8 \%$ BV decreased the feed intake. The reduction in the feed intake might be due to the strong taste associated with BV decreasing palatability of the feed. In this study, supplementation of $\mathrm{BV}$ at $0.4 \%, 0.6 \%$, and $0.8 \%$ levels decreased the $E$. coli population in the laying ducks, while the presence of Lactobacillus spp. remained unchanged. This result may be due to the active ingredients in bamboo vinegar that reduces the growth of harmful bacteria but maintains the existence of beneficial bacteria. Yan et al. (2012) found that addition of $\mathrm{BV}$ in the diet of fattening pigs could decrease the number of $E$. coli in feces caused by the rich phenols, ketones, and organic acids contents in the BV products. Watarai \& Tana (2005) also found that wood vinegar added to the diet of chickens inhibited the growth of pathogenic bacteria, but promoted the growth of beneficial bacteria. In the study of Chu et al. (2013) the populations of coliform bacteria and Salmonella in the feces were lower in pigs fed diet supplemented with BV. However, a higher level of BV in the diet may affect the balance of gut microflora. Wang et al. (2012) also stated that the quantity and diversity index of fecal bacteria were reduced in pigs fed diet with high levels of $\mathrm{BV}$, indicating that the buffering capacity of intestinal microflora might be affected by the high doses of BV. This might be another reason why the ducks fed diet supplemented with BV at the level of $0.8 \%$ had similar performance to the control ducks, in addition to the reduced feed intake.

\section{CONCLUSION}

The results of this study demonstrate that a level of $0.4 \%$ BV supplementation in laying duck diet is sufficient for reducing pathogenic gut bacteria and improves the productive performance of egg laying ducks.

\section{CONFLICT OF INTEREST}

We declare there is no conflict of interest with any financial, personal, or other relationships with other people or organization related to the material discussed in the manuscript.

\section{ACKNOWLEDGEMENT}

This work was financially supported by the Prince of Songkla University, Surat Thani Campus, 2016.

\section{REFERENCES}

Akakabe, Y., Y. Tamura, S. Iwamoto, M. Takabayashi, \& T. Nyuugaku. 2006. Volatile organic compounds with characteristic odor in bamboo vinegar. Biosci. Biotechnol. Biochem. 70:2797-2799. https://doi.org/10.1271/bbb.60317

Chan, E.W., Y.P. Tan, S.J. Chin, \& L.Y. Gan. 2012. Antioxidant and anti-tyrosinase properties of wood vinegar from Matang mangroves, Malaysia. ISME/G LOMIS Electron. J. 10:19-21.

Chu, G.M., C.K. Jung, H.Y. Kim, J.H. Ha, J.H. Kim, M.S. Jung, S.J. Lee, Y. Song, R.I.H. Ibrahim, J.H. Cho, S.S. Lee, \& Y.M. Song. 2013. Effects of bamboo charcoal and bamboo vinegar as antibiotic alternatives on growth performance, immune responses and fecal microflora population 
in fattening pigs. Anim. Sci. J. 84:113-120. https://doi. org/10.1111/j.1740-0929.2012.01045.x

Hedayati, M., M. Manafi, M. Yari, \& P. Vafaei. 2013. Effects of supplementing diets with an acidifier on performance parameters and visceral organ weights of broilers. Euro. J. Zool. Res. 2:49-55.

Huo, Y., Z. Liu, H. Xuan, C. Lu, L. Yu, W. Bao, \& G. Zhao. 2016. Effects of bamboo vinegar powder on growth performance and mRNA expression levels of interleukin-10, interleukin-22, and interleukin-25 in immune organs of weaned piglets. Anim. Nutr. 2:111-118. https://doi.org/10.1016/j. aninu.2016.02.006

Kil, D.Y., W.B. Kwon, \& B.G. Kim. 2011. Dietary acidifiers in weanling pig diets: a review. Rev. Colomb. Cienc. Pecu. 24:231-247.

Mabelebele, M., O.J. Alabi, J.W. Ngambi, D. Norris, \& M.M. Ginindza. 2014. Comparison of gastrointestinal tracts and $\mathrm{pH}$ values of digestive organs of Ross 308 broiler and indigenous Venda chickens fed the same diet. Asian J. Anim. Vet. Adv. 9:71-76. https://doi.org/10.3923/ajava.2014.71.76

NRC. 1994. Nutrient Requirements of Poultry. 9th rev. Ed. National Academy Press, Washington, DC.

Pacheco-Ordaz, R., A. Wall-Medrano, M.G. Go-ni1, G. RamosClamont-Montfort, J.F. Ayala-Zavala1 \& G.A. Gonz_alezAguilar. 2017. Effect of phenolic compounds on the growth of selected probiotic and pathogenic bacteria. Lett. Appl. Microbiol.66:25-31. https://doi.org/10.1111/lam.12814

Papatsiros, V.G. \& G. Christodoulopoulos. 2011. The use of organic acids in rabbit farming. Online J. Anim. Feed Res. 1:434-438

Rattanawut, J., O. Pimpa, \& K. Yamauchi. 2018. Effects of dietary bamboo vinegar supplementation on performance, eggshell quality, ileal microflora composition, and intestinal villus morphology of laying hens in the late phase of production. Anim. Sci. J. 89:1572-1580. https://doi. org/10.1111/asj.13080

Swiatkiewicz, S., J. Koreleski, \& A. Arczewska. 2010. Laying performance and eggshell quality in laying hens fed diets supplemented with prebiotics and organic acids. Czech J. Anim. Sci. 55:294-306. https://doi. org/10.17221/207/2009-CJAS

Velmurugan, N., S.S. Chun, S.S. Han, \& Y.S. Lee. 2009. Characterization of chikusaku-eki and mokusaku-eki and its inhibitory effect on sapstaining fungal growth in laboratory scale. Int. J. Environ. Sci. Technol. 6:13-22. https:// doi.org/10.1007/BF03326056

Wang, H.F., J.L. Wang, W.M. Zhang, J.X. Liu, \& B. Dai. 2012. Effect of bamboo vinegar as an antibiotic alternative on growth performance and fecal bacterial communities of weaned piglets. Livest. Sci. 144:173-180. https://doi org/10.1016/j.livsci.2011.11.015

Watarai, S. \& Tana. 2005. Eliminating the carriage of Salmonella enterica serovar Enteritidis in domestic fowls by feeding activated charcoal from bark containing wood vinegar liquid (Nekka-rich). Poult. Sci. 84:515-521. https://doi. org $/ 10.1093 / \mathrm{ps} / 84.4 .515$

Yan, L., I.H. Kim, \& K. Huh. 2012. Influence of bamboo vinegar supplementation on growth performance, apparent total tract digestibility, blood characteristics, meat quality, fecal noxious gas content, and fecal microbial concentration in finishing pigs. Livest. Sci. 144:240-246. https://doi. org/10.1016/j.livsci.2011.11.020

Yang, J.F., C.H. Yang, M.T. Liang, Z.J. Gao, Y.W. Wu, \& L.Y. Chuang. 2016. Chemical composition, antioxidant, and antibacterial activity of wood vinegar from Litchi chinensis. Molecules. 21:1-10. https://doi.org/10.3390/ molecules21091150 